International Journal of Current Advanced Research

ISSN: O: 2319-6475, ISSN: P: 2319 - 6505, Impact Factor: SJIF: 5.995

Available Online at www.journalijcar.org

Volume 6; Issue 5; May 2017; Page No. 3892-3893

DOI: http://dx.doi.org/10.24327/ijcar.2017.3893.0389

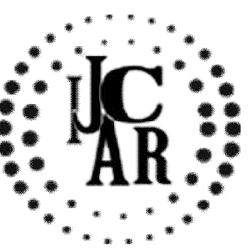

Case Report

\title{
LYME DISEASE
}

Prathipa.V

Department of Child Health Nursing, SreeBalaji College of Nursing, Bharath University, Tamilnadu, India

\section{A R T I C L E I N F O}

\section{Article History:}

Received $24^{\text {th }}$ February, 2017

Received in revised form $12^{\text {th }}$ March, 2017

Accepted $8^{\text {th }}$ April, 2017

Published online $28^{\text {th }}$ May, 2017

\section{Key words:}

Erythema, Spirochete, palpitations, disease, bacteria.

\begin{abstract}
A B S T R A C T
Lyme disease, also known as Lyme borreliosis, is an infectious disease caused by bacteria of the Borrelia type. The most common sign of infection is an expanding area of redness, known as erythema migrans, that begins at the site of a tick bite about a week after it has occurred. The rash is typically neither itchy nor painful. Approximately $25-50 \%$ of infected people do not develop a rash. Other early symptoms may include fever, headache and feeling tired. If untreated, symptoms may include loss of the ability to move one or both sides of the face, joint pains, severe headaches with neck stiffness, or heart palpitations, among others. Months to years later, repeated episodes of joint pain and swelling may occur. Occasionally, people develop shooting pains or tingling in their arms and legs. Despite appropriate treatment, about 10 to $20 \%$ of people develop joint pains, memory problems, and feel tired for at least six months.
\end{abstract}

Copyright $₫ 2017$ Prathipa.V. This is an open access article distributed under the Creative Commons Attribution License, which permits unrestricted use, distribution, and reproduction in any medium, provided the original work is properly cited.

\section{INTRODUCTION}

\section{Definition}

An inflammatory disease that is caused by the bacterium Borreliaburgdorferi, which is transmitted to humans by the deer tick.

\section{Signs and Symptoms}

- Bull's eye rash or erythema migrans

- Fever, headache

- Lethargy, Neck stiffness

- $\quad$ pain and swelling in the joints (inflammatory arthritis)

- numbness and pain in your limbs

- paralysis of your facial muscles

- memory problems and difficulty concentrating

- heart problems-such as inflammation of the heart muscle (myocarditis) or sac surrounding the heart (pericarditis)

- heart block and heart failure

- inflammation of the membranes surrounding the brain and spinal cord (meningitis) - which can cause a severe headache, a stiff neck and increased sensitivity to light.

\section{Risk Factors}

1. The New Forest and other rural areas of Hampshire

2. The South Downs, parts of Wiltshire and Berkshire

\section{*Corresponding author: Prathipa.V}

Department of Child Health Nursing, SreeBalaji College of Nursing, Bharath University, Tamilnadu, India
3. The Lake District

4. The Scottish Highlands Causes

- Borreliascapularis

- Ixodesscapularis

- Mammals \& birds by ticks

Pathophysiology: due to the causes bite of an infected Ixodestick- tick salaiva accompanies the spirochete - this allows the bacteria to survive \& eventually spread throughout the body-spread via blood stream to joints, heart, nervous system, skin sites - Lyme disease.

\section{Diagnostic Evaluation}

- History collection

- Physical examination

- Serological blood tests. Eg: ELISA, Western blot

- Culturing

- Polymerase chain reaction

- Cereberospinal fluid specimens

- High titers IgG or IgM.

\section{Treatment}

- Antibiotics: Doxycycline, Amoxicillin, Azithromycin, Cefotaxime.

- Symptomatic treatment.

\section{Prevention}

- $\quad$ keeping to footpaths and avoiding long grass when out walking 
- $\quad$ wearing appropriate clothing in tick-infested areas (a long-sleeved shirt and trousers tucked into your socks)

- wearing light-coloured fabrics that may help you spot a tick on your clothes

- $\quad$ using insect repellent on exposed skin

- inspecting your skin for ticks, particularly at the end of the day, including your head, neck and skin folds (armpits, groin, and waistband) - remove any ticks you find promptly

- checking your children's head and neck areas, including their scalp

- making sure ticks are not brought home on your clothes

\section{Reference}

1. Shapiro, ED (1 May 2014). "Clinical practice.Lyme disease."(PDF).The New England Journal of Medicine. 370 (18): 1724-31. doi:10.1056/NEJMcp1314325. PMID 24785207.

2. "Signs and Symptoms of Lyme Disease". cdc.gov. January 11, 2013. Archived from the original on Jan 16, 2013. Retrieved 2 March 2015.

3. Aucott JN (2015). "Posttreatment Lyme disease syndrome". Infectious Disease Clinics of North America. 29 (2): 309-23.doi:10.1016/j.idc.2015. 02.012. PMID 25999226.

4. Johnson RC (1996). "Borrelia". In Baron S et al. Baron's Medical Microbiology (4th ed.). Univ of Texas Medical Branch. ISBN 0-9631172-1-1. PMID 21413339.

5. "Lyme disease transmission". cdc.gov. January 11, 2013. Retrieved 2 March 2015.

6. "Lyme Disease Diagnosis and Testing". cdc.gov. January 10, 2013. Retrieved 2 March 2015.

7. "Two-step Laboratory Testing Process". cdc.gov. November 15, 2011. Retrieved 2 March 2015.

\section{How to cite this article:}

Prathipa.V (2017) 'Lyme Disease', International Journal of Current Advanced Research, 06(05), pp. 3892-3893.DOI: http://dx.doi.org/10.24327/ijcar.2017.3893.0389 